\title{
稀有なる舌の骨軟骨腫の一症例
}

\author{
佐藤 幸雄・小川 克二・大内 仁
}

\section{A Case of Osteochondroma of the Tongue}

\section{Yukio Satoh, Yoshitsugu Ogawa and Jin Ouchi}

(Fukushima Medical College)

A case of osteochondroma of the tongue was reported with a review of the literature.

A 27-year-old woman was seen on August 19, 1975, with the complaint of "something growing on the tongue". The lesion had increased in size in 23 years. A mass about the size of a walnut was found on the left side of the middle third of the tongue.

The lesion was removed under general anesthesia on October 17, 1975.

Benign bony and cartilagenous tumors of the tongue are quite rare. In the world-wide literature on the subject, 13 cases of osteoma, 17 cases of chondroma and 3 cases of osteochondroma were reported.

The exact etiology of those lesions is not known, but two theories have generally been advanced to account for the formation of bony and cartilaguenous tumors of the tongue: the congenital theory and the metaplastic theory.

The lesion in this case appeared to be metaplastic in origin.

緒 言

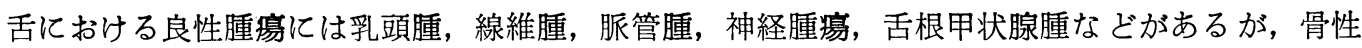
又は軟骨性腫演は極めて稀有なものとされている32).

最近我々は27才の女性の舌に生じた骨軟骨腫の一症例を経験したので報告すると共に，乙れと密 接な関係にある骨腫や軟骨腫と併せて文献的考察を行なった。

症

患者:—27才, 女性.

初診：昭和50年 8 月 19 日.

主訴 : 舌の腫瘍形成.

家族歷：特記すべき事なし.

現病歴：4才の頃某医にて舌の腫瘍形成を指 摘された. 腫煬はその後でく緩慢に増大した が, 軽度の発語障害を認めるのみであり, 放置 していた。昭和 50 年 7 月頃（26才）より左舌縁
例

に軽度の疼痛が認められるようになった為, 当 科外来を受診した。

入院：昭和 50 年 10 月 8 日.

現症：入院時所見としては全身的に特に異常 を認めなかった．胸部 X線写真, 心電図にも異 常なく, 一般検查成績屯第 1 表に示すごとく特 に異常を認めなかった。

局所所見 : 第 1 図のごとく舌中 $1 / 3$ の左側部が 


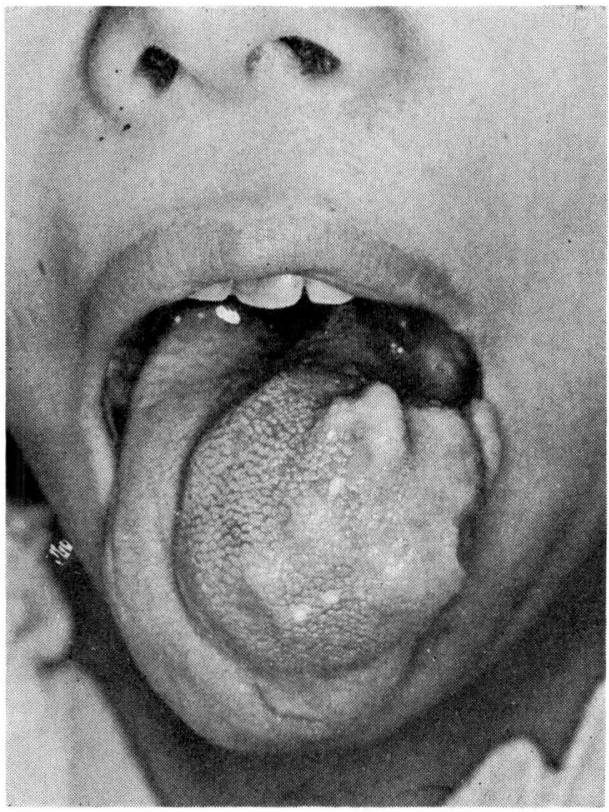

第｜図 局所所見

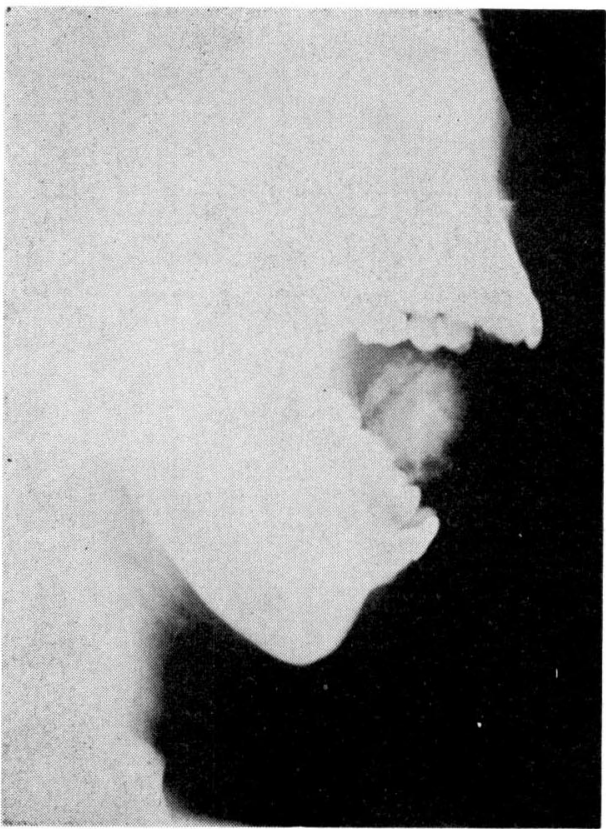

第 2 図 舌腫湯のX線写真 腫湯に一致し, 濃厚な陰 影を認める.
第 | 表 入院時検査成績

血液検査

$\mathrm{RBC} 402 \times 10^{4} \mathrm{Hb} 13.2 \mathrm{~g} / \mathrm{dl}$ Hct $38.9 \%$

WBC 5100 Blood Plat, $19.4 \times 10^{4}$

尿検查

Prot, (-) Urobil (N)

肝機能検査

GOT 39 RFU GPT 23 RFU

血清電解質

Na $138 \mathrm{~K} 4.1 \mathrm{Cl} 104 \mathrm{Ca} 4.8 \mathrm{mEq} / \mathrm{dl}$

ワ氏反応陰性

赤沈值 $\quad 12 \sim 31 \mathrm{~mm}$

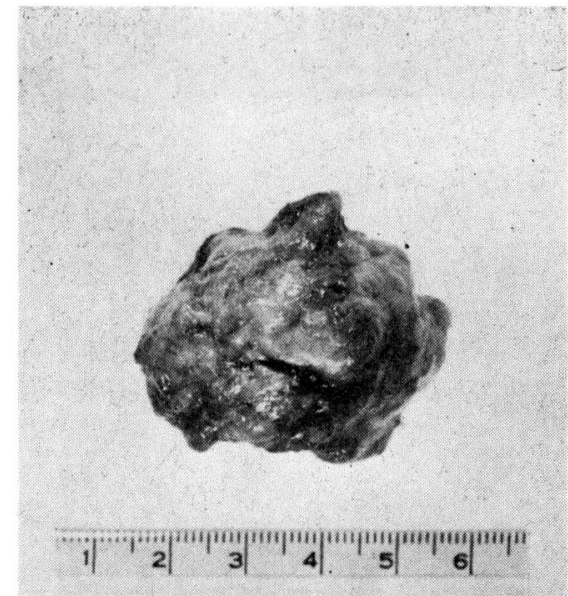

第 3 図 摘出した舌腫煬

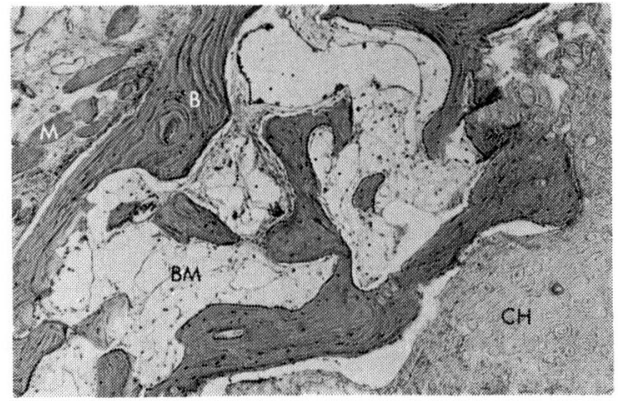

第 4 図 組織所見 $(\times 60)$

軟骨組織（C H）は硝子軟骨. 骨組織（B）には

Harvers 管, 層板構告, 骨梁構造を認める。骨檤 （BM）は脂肪膸より成る. 腫場周囲には萎縮した横 紋筋束 (M) 疎結合組織を認める. 
腫脹しており, その粘膜下にクルミ大で, 表面 が凹凸不平で, 非常に硬く骨性硬の腫瘍が触知 された. 舌左縁の粘膜に歯牙による刺激の為と 思われる軽度のびらんを認めた。発語の際所謂 kloßige Sprache が認められたが, 鼻腔咽喉頭 には特に異常を認めなかった，又，局所の単純 $\mathrm{X}$ 線写真で腫瘍に一致して濃厚な陰影を認めた (第 2 図).

手術所見：10月17日全身麻酔下に舌腫演摘出 術を施行した. 舌背中央よりやや左側の粘膜に 切開を加えた所, 腫瘍は筋層内に存在し, 周囲 の組織との癒着はなく摘出は容易であった，腫 瘍摘出後筋層をクロミックカットグートで縫い 合わせ，粘膜を絹糸で縫合し手術を終えた。

術後経過は良好で，11月 1 日退院した。昭和 54年10月現在再発を認めていない.

病理学的所見：摘出標本は骨腫様で非常に硬

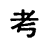

舌の骨性又は軟骨性腫瘍は甚だ稀なあのであ り, 我々が内外の文献を涉猟した範囲では現在 まで第 2，3，4 表のごとく骨腫が Monsarr$\mathrm{at}^{11}$ （1913）以来13例, 軟骨腫が Berry ${ }^{15)}$ (18 92) 以来17例, 骨軟骨腫が Neumark ら ${ }^{30)}(19$ 30）以来本例を入れて 4 例の報告があるのみで ある.

これらの骨性又は軟骨性腫瘍の報告例を統計 的にまとめてみると, 性別において, 骨腫は女 性が11例, 男性が 2 例とそのほとんどの症例が 女性であった。これに対して軟骨腫は女性が 9 例，男性が 8 例之性別に差はなかった，骨軟骨 腫は症例数が少ないが, 不明の一例をのぞいて, 本例を含めて 3 例全例が女性であった。

年令では, 骨腫は20才〜30才台がほとんどで

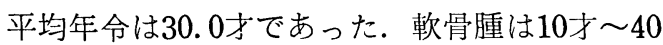
才台に略均等に分布しており，不明の 3 例をの ぞいた14例の平均年令は31.6才であった。骨軟 骨腫は20才台 2 例, 50 才台 1 例, 不明 1 例で, 3 例の平均年令は 35.0 才であった。 これらの 3 種類の腫瘍は既して比較的若い年令層に多いよ
く数個の突起を有し, 略球形でその大きさは長 径 $3.5 \mathrm{~cm}$, 重量は $29 \mathrm{~g}$ であり, 割面は黄白色を 呈していた（第3図）.

病理組織学的診断は骨軟骨腫であった（第 4 図). 軟骨組織は硝子軟骨であり, 軟骨細胞は 大型, 類円形で, 数個あるいは $2 \sim 3$ 個迄の細 胞が密接し, 軟骨小囊につつまれていた。骨組 織は軟骨細胞層の肥大, 増大, 次に軟骨基質へ の石灰沈着がおこり軟骨細胞の萎縮, 骨組織へ の移行と言う典型的な軟骨性化骨化によるもの であった。骨組織は Harvers 管, 層板構造, 骨梁構造を備えており, 骨髄は主として脂肪髅 より成り拡張した毛細管が散在していた。腫場 の周囲には萎縮した横紋筋束や疎結合組織が認 められるが，乙れらの組織には炎症像は全く認 められず, 本腫瘍との間には移行像は認められ なかった。

\section{按}

うである。

発生部位では，骨腫はほとんどが舌後 $1 / 3$ の部 之略一定しており，その多くが舌盲孔に近接し て認められた。とれに比して軟骨腫では発生部 位は様々であり, 舌前 $1 / 3$ の部又は舌縁が, 不明 の 3 例をのぞいた 14 例中 8 例と半数を占めてい た，骨軟骨腫は不明の 1 例をのぞいた 2 例共舌 後 $1 / 3$ の部であったが, 本例は舌中 $1 / 3$ の部であっ た.

症状では骨腫, 軟骨腫共に無症状が最も多い が, なかには嚥下困難, 舌の腫瘍, 呕気, 舌痛 等が認められるものも僅かながらあるようであ った.

腫瘍の大きさでは，骨腫は踠豆大から直径 1 $\mathrm{cm}$ まで, 軟骨腫は直径 $0.3 \mathrm{~cm}$ のものら $13 \times 10$ cmのものまで, 惄軟骨腫は直径 $1.2 \mathrm{~cm}$ あのと クルミ大のもので, 本例では直径が略 $3.5 \mathrm{~cm}$ で あった。

最後に治療であるが，骨腫，軟骨腫，骨軟骨 腫のいづれもほとんどの症例で摘出手術をおこ なっている，本例に执いて屯摘出手術により治 
第 2 表 骨 腫

\begin{tabular}{|c|c|c|c|c|c|c|c|}
\hline 著 & 年代 & 性 & 年令 & 発生部位 & 症 & <大きさ> & 治療 \\
\hline Monsarrat ${ }^{11}$ & 1913 & $\mathrm{~F}$ & 32 & 舌後部中央 & 無症状 & 桜桃大 & 摘出 \\
\hline Hirsch $^{21}$ & 1925 & $\mathrm{~F}$ & 26 & 舌根部 & 曣下困難 & 桜桃大 & 摘出 \\
\hline Zuckermann $^{3)}$ & 1929 & $\mathrm{~F}$ & 30 & 有郭乳頭部中央 & 無症状 & 䭪豆大 & 摘出 \\
\hline Jung4) & 1931 & $\mathrm{~F}$ & 22 & 舌盲孔部 & 咽頭過敏 & $1 \times 0.5 \mathrm{~cm}$ & 摘出 \\
\hline Magnien et al6) & 1933 & $\mathrm{~F}$ & 37 & 舌後 $1 / 3$ ～中 $1 / 3$ 境界部 & 咽頭異常感 & $0.6 \times 0.5 \times 0.4 \mathrm{~cm}$ & 摘出 \\
\hline 牟田ら7) & 1938 & M & 23 & 有郭乳頭部中央 & 嚥下困難, 舌腫煌形成 & 踠豆大 & 摘出 \\
\hline Witchell8) & 1949 & $\mathrm{~F}$ & 30 & 有郭乳頭部 & 嘔気, 嘔吐 & $1 \mathrm{~cm}$ & 摘出 \\
\hline $\begin{array}{c}\text { Breckenrige et } \\
\mathrm{al}^{9}{ }^{9}\end{array}$ & 1950 & $\mathrm{~F}$ & 23 & 有郭乳頭部中央 & 無症状 & $1 \mathrm{~cm}$ & 摘出 \\
\hline Peimer et al10) & 1956 & $\mathrm{~F}$ & 27 & 郭乳頭部中央 & 嘔＼cjkstart気 & $0.7 \times 0.6 \times 0.3 \mathrm{~cm}$ & 摘出 \\
\hline Church11) & 1964 & $\mathrm{~F}$ & 11 & 舌盲孔部 & 腫瘍形成 & $0.5 \mathrm{~cm}$ & 摘出 \\
\hline Cataldo et al12) & 1967 & $\mathrm{~F}$ & 39 & 有郭乳頭部中央 & 無症 状 & $1 \mathrm{~cm}$ & 摘出 \\
\hline Begel et al13) & 1968 & $\mathrm{~F}$ & 22 & 有郭乳頭部 & 曣下困難 & $1 \times 0.5 \mathrm{~cm}$ & 摘出 \\
\hline Goldberg et al14) & 1970 & M & 65 & 有郭乳頭部 & 無症状 & $0.8 \times 0.5 \times 0.3 \mathrm{~cm}$ & 摘出 \\
\hline
\end{tabular}

第 3 表 軟骨腫

\begin{tabular}{|c|c|c|c|c|c|c|c|c|}
\hline 著 & 年代 & 性 & 年令 & 発生部位 & 症 & 大きさ & 治 & 療 \\
\hline Berry 15) & 1892 & M & 49 & 舌 縁 & 不 明 & 不 明 & 不 & 明 \\
\hline Lang ${ }^{15)}$ & 1892 & $\mathrm{~F}$ & 22 & 不 明 & 不 明 & 不 明 & 不 & 明 \\
\hline Routier ${ }^{16)}$ & 1905 & $\mathrm{~F}$ & 不明 & 不 明 & 不 明 & 不 明 & 摘 & 出 \\
\hline Camns et al17) & 1905 & $\mathrm{~F}$ & 21 & 舌前部舌縁 & 不 明 & 不 明 & 不 & 明 \\
\hline Huie $^{18)}$ & 1927 & $\mathrm{~F}$ & 不明 & 不 明 & 曣下困難 & $13 \times 10 \mathrm{~cm}$ & 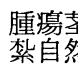 & 器部結落 \\
\hline Pless ${ }^{19)}$ & 1936 & $\mathbf{M}$ & 39 & 舌 尖 & 無症状 & クルミ大 & 摘 & 出 \\
\hline 秋山 20) & 1941 & $\mathbf{M}$ & 12 & 舌 尖 & 無症状 & $3.0 \times 2.7 \times 2.0 \mathrm{~cm}$ & 摘 & 出 \\
\hline Johns 21 ) & 1942 & $M$ & 不明 & 舌尖前 $1 / 3$, 右舌縁 & 無症状 & 不 明 & 摘 & 出 \\
\hline 種村ら 22) & 1944 & $\mathrm{~F}$ & 38 & 舌中1/3, 舌背 & 舌異常感 & 踠豆大 & 摘 & 出 \\
\hline Bruce et al 23 ) & 1953 & M & 52 & 舌前部, 右舌縁 & 無症状 & $0.5 \mathrm{~cm}$ & 摘 & 出 \\
\hline Bruce et $\mathrm{al}^{23}$ ) & 1953 & $\mathrm{~F}$ & 43 & 舌中 $1 / 3$, 舌背 & 無症状 & $0.3 \mathrm{~cm}$ & 摘 & 出 \\
\hline Rosen $^{24)}$ & 1961 & M & 36 & 舌 尖 & 舌 痛 & $0.3 \mathrm{~cm}$ & 摘 & 出 \\
\hline Yoel et al25) & 1965 & $M$ & 36 & 舌後 $1 / 3$, 右舌縁 & 無症状 & $4.5 \times 1 \mathrm{~cm}$ & 摘 & 出 \\
\hline Ramachandran et al26) & 1968 & $\mathrm{~F}$ & 10 & 舌中 $1 / 3$, 右側 & 舌腫煌形成 & $1 \mathrm{~cm}$ & 摘 & 出 \\
\hline Viglioglia et a127) & 1970 & $\mathrm{~F}$ & 26 & 舌中 $1 / 3$ 〜後 $1 / 3$ 舌背 & 舌腫焬形成 & $3 \mathrm{~cm}$ & 摘 & 出 \\
\hline Samant et al28) & 1971 & M & 16 & 舌後1/3, 右舌背 & 舆下異常感 & 不明 & 摘 & 出 \\
\hline Gutmann et al ${ }^{29}$ ) & 1974 & $\mathrm{~F}$ & 42 & 舌中1/3, 中央 & 無症状 & $1.3 \times 0.7 \mathrm{~cm}$ & 摘 & 出 \\
\hline
\end{tabular}

第 4 表 骨軟骨腫

\begin{tabular}{|c|c|c|c|c|c|c|c|c|}
\hline 著 者 & 年代 & 性 & 年令 & 発生部位 & 症 状 & 大きさ & 治 & 療 \\
\hline Neumark et $\mathrm{al}^{30}$ ) & 1930 & $\mathrm{~F}$ & 58 & 舌根部 & 曣下困難 & クルミ大 & 摘 & 出 \\
\hline Noil et al31) & 1956 & 不明 & 不明 & 不 明 & 不 明 & 不 明 & 不 & 明 \\
\hline Roy et a132) & 1970 & $\mathrm{~F}$ & 20 & 舌盲孔部 & 舌 痛 & $1.2 \mathrm{~cm}$ & 摘 & 出 \\
\hline 著者ら & 1980 & $\mathrm{~F}$ & 27 & 舌中 $1 / 3$, 左側 & 舌腫煌形成 & $4 \times 3.5 \times 3.5 \mathrm{~cm}$ & 摘 & 出 \\
\hline
\end{tabular}


檷せしめた。

次に骨性又は軟骨性腫瘍の発生原因である が, 舌等の軟部組織には骨性又は軟骨性組織が 存在しないのが普通である. 従っててれらの軟 部組織に生じた骨性又は軟骨性腫湟の発生原因 に関しては, 胎生期における骨性又は軟骨性原 基の遺残又は迷入等の先天性説及び外傷又は慢 性炎症等により間葉組織が後天性に骨又は軟骨 への化生がおてるとする化生説が主たるもので ある.

骨腫の成因については，13例の報告例の殆ん ぞが比較的若年層の女性で, 発生部位において もその多くが舌後 $1 / 3$ の部, 特に舌盲孔に近接し て認められる事より, 胎生期における鰓弓での 化骨化の際の骨芽細胞の遺残又は迷入より生じ たあのではないかとする先天性説が主である11 3) 4) 10).

舌盲孔は甲状腺発生に先立ち出現する甲状舌 管が閉鎖した時の舌における開口部であるとさ れている. 従って Roy ら ${ }^{32)}$ は甲状舌管がその 発達途中で舌骨を貫くか又は舌骨に密着してい る事より, 舌骨の骨軟骨性間葉織が舌盲孔部へ の移動又は遊走をおこす可能性があるとしてい る. 又, Caraldo ら ${ }^{12)}$ は先天異常である舌根甲 状腺腫の大半が女性にみられる事より, 甲状腺 の原基の遺残が骨腫の発生に関与しているので はないかと述べている。

一方, Greig' ${ }^{5)}$ は後天的にあ骨腫が生じる可 能性があるとし, 舌後部は動きが少なく，乙の 部に生じた線維組織はその代謝を保つのに必要 な血流が得られず, 変性に落ち入り骨への化生 をおこす事があるのではないかと推定してい る.

軟骨腫の成因については先天性説, 化生説が 略折半してあるようである. その理由は我々の 統計でみられるようにその発生部位では舌前 $1 / 3$ の部又は舌縁が半数を占めているものの, 骨腫 のごとくかならずしも一定して抢らず，又性別 であ男女差が認められない為であろうと思われ

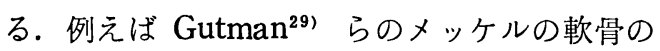

痕跡的遺残より発生する軟骨組織の異所性増殖 であるとする説, 秋山ら ${ }^{20)}$ は Gentscheff の成 熟児及び新生児の舌中隔の下に約 $30 \%$ 存在する と言われる軟骨組織が成人においてす認められ たのだとする説を重視している，又，Bruceら ${ }^{23)}$ は, 結合組織の軟骨又は骨への化生は主とし て外傷，慢性炎症等で抏こるとした Anderson 33)の説をもとに，〈りかえされる外傷により未 分化の中胚葉由来細胞が軟骨に変化するとする 説を上げているが，いづれあ定説とはなってい ない.

いづれにせよ骨腫又は軟骨腫の成因について は主として腫陽の発生部位により推定されてい るようである。このような観点から Roy ら ${ }^{32)}$ は骨性又は軟骨性腫瘍を発生部位によって 2 つのグループに分け, その 1 つのグループは舌 盲孔付近に認められる骨腫が主体のもの，むう 1 つのグループは外傷を頻回に受けやすい舌前 部又は舌縁に認められる軟骨腫が主体のものに 2 分している. 前者のグループは迷入した多潜 能力の中胚葉性胚芽遺残によるもの, 後者のグ ループは外傷後の中胚葉性の化生によるもの之 推定しているが, 著者は現時点ではこの説が最 あ妥当なあのであると考える.

骨軟骨腫は前述のごとく Neumark ら ${ }^{30)}$ 以 来本例を含めて 4 例の報告がある，その成因之 しては Noliin らの 1 例は詳細が不明である が, Neumark ら ${ }^{30)}$ は間質の慢性炎症によるも の，むしくは先天性の散在した胚芽の増殖によ るものと考えられる骨又は軟骨組織が扁桃に認 められる事が一般に知られている事より, 同様 の骨又は軟骨組織が舌根扁桃に認められても不 思議ではないとしている。 Roy ら ${ }^{32)}$ はすでに 述べたでとく腫瘍発生部位が舌盲孔に接してい る事より先天性説を推定している.てれらの諸 説は骨腫又は軟骨腫の成因についての考えと略 同様のものに立脚したものであるが, Bruceら 23) は Ewing が軟骨はたやすく骨へ化生しやす いと述べている事より, 骨腫のあるものは軟骨 腫の変化したものであろうと推定しており，骨 
軟骨腫は何等かの原因で舌に生じた軟骨腫の一 部が骨腫への化生をみたものとも考えられる.

本例においては女性で，4才の幼少時より腫 瘍が認められるが，その発生部位は舌中 $1 / 3$ 左側 で舌盲孔とは関連を認めないとと，組織学的に
明らかな軟骨性化骨変化を呈していたてとよ り，本例は本来は化生によって生じた軟骨腫で あり，その一部が化骨変化を受けたものと推定 される。

結

語

27才女性の舌に発生した骨軟骨腫の一症例について報告し，あわせてその発生原因などについて 若干の文献的考察をおこなった。

文

1) Monsarrat, M. : Ostéomae de la langue, $\mathrm{Bu}$ 11. et mén. Soc. Anat. Paris. $88: 282 \sim 283$, 1913.

2 ) Hirsch, O.: Knochentumor am Zungengrund, Monatsschr. Ohrenh. $59:$ 496 497, 1925.

3) Zuckerman, M. : Ein Fall von Osteom der Zunge, Ztschr. Hals-Nasen-u. Ohrenh. 25 : $118 \sim 120,1929$.

4) Jung, G. : Über ein Osteom der Zunge, Beitr. Klin. Chir. I54:167 168, 1931.

5 ) Greig, D. M. : Osteoma of Tongue, Critical Review, Edinburgh M. J. $39: 93 \sim 104$, 1932.

6) Magnien and Perrot, M. : Umcase dósteome de la langue, Ann. Anat. Path. 10:331 334, 1933.

7 ）车田哲三郎, 緒方健 : 舌根部骨腫症例追加. 耳喉 科 II: 1016 1017, 1938 .

8 ) Witchell, I.: Osteoma of the Tongue, Arch. Otolaryng. 50: 453 456, 1949.

9 ) Breckenridge, R. L., and Lukens, R. M. : Osteoma of the Tongue, Arch. Otolaryng. $52: 19 \sim 24,1950$.

10) Peimer, R., Dreizin, D. H., and Masugi, Y. : Osteoma of the Tongue, Arch. Otolaryng. $64: 148 \sim 150,1956$.

11) Church, L. E. : Osteoma of the Tongue, Report of a Case, J. Oral Surg 17:768 770, 1964.

12) Catataldo, E., Shklar, G., and Meyer, I. : Osteoma of the Tangue, Arch. Otolaryng.

\section{献}

$85: 202 \sim 206,1967$.

13) Begel, H., Wilson, H., Stratigos, G., and Zambito, R. F. : Osteoma of the Tongue ; Report of Case, J. Oral Surg 26:662 664, 1968.

14) Goldberg, A. F., Skuble, D. F., and Latronica, R. J. : Osteoma of the Tongue; Report of case, J. Oral Surg $28: 457 \sim 458,1970$.

15) Butlin, H. T., and Spencer, W. G.: Disease of the Tongue, London, 1900, Cassell \& Co., Ltd., P. 285. Yoel, J., and Pundyk, C. : Chondroma of the Tongue, Oral Surg., Oral Med. \& Oral Path. $20: 578 \sim 582,1965$, より引用.

16) Routier, M.: Enchondrome de la langue, Bull. et men. Soc. d.chirurgiens de Paris, 31 : 369 370, 1905.

17) Camus, M., and Ertzbeschoff, B. : Chondroma de la langue chez une jeune femme, Bull. et, men. Soc. anat. de Paris. $30: 301 \sim$ 302, 1905.

18) Fitzwilliams, D. C. L. : The Tongue and Its Disases, London, 1927, Oxford University Press, P. 327. Yoel, J., and Pundyk, C. : Chondroma of the Tongue, Oral Surg., Oral Med. Oral Path. $20: 578 \sim 582,1965$.

19) Pless, B.: Der Fall eines Chondroms der Zungenspitze, Zahnaerzth. Pundsch. 45 : 514 515, 1936.

20）秋山卓三：稀有なる舌の内軟骨腫の一例. 日本外 科宝函 18:1067, 1941 .

21) Johns, J. : Chondroma of the Tongue, J. Mi- 
chigan M Soc. $4 \mid \cdots 471 \sim 472,1942$.

22）種村竜夫，山岸久夫：舌に於ける良性腫煬に就て ; 舌軟骨腫の一例. 大日耳鼻 $50: 30 \sim 33,1944$.

23) Bruce, K. W., and Mcdonald, J. R. : Chondroma of the Tongue, Oral Surg., Oral Med \& Oral Path. $6: 1281 \sim 1283,1953$.

24) Rosen, M. D. : Chondroma of the Tongue ; Report of a Case, J. Oral Surg., Anesth. \& Hosp. D. Serv. 19:157 159, 1961.

25) Yoel, J., and Pundyk, C. : Chondroma of the Tongue, Oral Surg., Oral Med. \& Oral Path. $20: 578 \sim 582,1965$.

26) Ramachandran, K., and Viswanathan, R. : Chodroma of a case' Oral Surg Med.\& Oral Surg., Oral Surg., Oral Med. \& Oral Path. $25: 487 \sim 490,1968$.

27) Viglioglia, P. A., and Stirparo, M. A. : Chondroma of the Tongue, Oral Surg. $29: 820$ $\sim 826,1970$.

28) Samant, H. C., and Gupta, O. P. : Chondroma of the Tongue, Oral Surg. $\quad 32: 450 \sim 452$, 1971.
29) Gutmann, J., Cifuentes, C., Balzarini, M. A., Sobarzo, V., and Vicuna, R. : Chondroma of the Tongue, Oral Surg. $37: 75 \sim 77,1974$.

30) Neumark, K. und Herzog, A. : Osteochondrom der zungengrundes, Monats. f. Ohrenheilk., Berlin, 64 : 1000 1003, 1930.

31) Noli, G., and Tusini, G. : Su di un caso di osteocondroma della lingua, Boill lat 9 : 272 280, 1956. Roy, J. J., Klein, H. Z., and Tipton, D. L.: Osteocondroma of the the Tongue, Arch Path $89: 565 \sim 568,1970$, より 引用.

32) Roy, J. J., Klein, H. Z., and Tipton, D. L. : Osteochondroma of the Tongue, Arch Path $89: 565 \sim 568,1970$.

33) Anderson, W. A. D. : Pathology, ed. 6, St. Louis, 1971, The C.V. Mosby Company, PP. 582 583, 1734 1736.

原稿到着: 昭和 55 年 9 月 30 日
別刷請求先: 佐藤幸雄
馬 960 福島市杉妻町 $5-75$
福島県立医科大学耳鼻咽喉科学教室

